DOI: $10.26418 /$ positron.v10i1.40113

\title{
Sebaran Salinitas Perairan Laut Kabupaten Bengkayang pada Musim Kemarau
}

\author{
Muhammad Ishak Jumaranga, ${ }^{\mathrm{a},}$, I Wayan Nurjaya ${ }^{\mathrm{b}}$, Agus S. Atmadipoera ${ }^{\mathrm{b}}$, Dietriech G. Bengen ${ }^{\mathrm{b}}$ \\ aProgram Studi Ilmu Kelautan, Departemen Ilmu dan Teknologi Kelautan, FPIK IPB, Bogor \\ ${ }^{\mathrm{b}}$ Departemen Ilmu dan Teknologi Kelautan, FPIK IPB, Bogor \\ cProgram Studi Geofisika, FMIPA Universitas Tanjungpura, Pontianak \\ *Email : ishakjumarang@physics.untan.ac.id \\ (Diterima 19 Maret 2020; Disetujui 30 Mei 2020; Dipublikasikan 16 September 2020)
}

\begin{abstract}
Abstrak
Telah dilakukan penelitian tentang sebaran salinitas perairan laut Kabupaten Bengkayang pada musim kemarau. Penelitian ini dilakukan dengan melalukan pengambilan data salinitas, suhu dan konduktivitas massa air berdasarkan kedalaman di 23 stasiun pengukuran. Lokasi penelitian berada pada koordinat 107,68 s.d 108,93 BT dan 0,69 LS s.d 0,87 LU. Lokasi penelitian terdiri atas lima lintasan yang membentang dari timur ke barat dan setiap lintasan terdiri atas empat stasiun pengamatan serta penambahan tiga stasiun pengukuran di sisi timur, barat dan selatan Pulau Lemukutan. Analisis dan visualisasi data massa air (suhu, salinitas, dan densitas) dilakukan dengan menggunakan perangkat lunak Ocean Data View (ODV) versi 4.7.6. Hasil analisis dan visualisasi data massa air menunjukkan bahwa salinitas massa air di perairan laut Kabupaten Bengkayang pada musim kemarau berada pada rentang 28,96 s.d 32,5 psu. Sebaran salinitas permukaan di daerah penelitian terbagi atas tiga bagian yaitu bagian utara, bagian tengah dan bagian selatan daerah penelitian, dengan tiap bagian membentang dari timur ke barat atau tegak lurus garis pantai. Massa air bersalinitas rendah (MABR) yang terjebak di bagian tengah diduga berasal dari massa air dari sungai yang terletak di bagian selatan pesisir Kalimantan yaitu Sungai Kapuas dan Sungai Mempawah. MABR tersebut terdorong dan bergerak ke arah utara sesuai dengan arah arus yang terjadi di pesisir Kalimantan Barat pada musim kemarau. Stratifikasi kolom air dalam kondisi stabil di seluruh daerah penelitian. Massa air yang bersalinitas kurang dari 30,5 psu ditemukan hingga kedalaman 4,5 meter di bagian barat daya, bagian selatan dan bagian tenggara Pulau Lemukutan. Massa air dengan salinitas 30,75 s.d 31,75 psu dapat dijumpai dari garis pantai hingga mencapai bagian barat Pulau Lemukutan dengan kedalaman sampai 10 meter dari permukaan.
\end{abstract}

Kata kunci: Kabupaten Bengkayang, Pulau Lemukutan, ROFI, salinitas

\section{Latar Belakang}

Kalimantan Barat merupakan salah satu propinsi di Indonesia yang dilalui oleh garis khatulistiwa dan memiliki garis pantai yang membentang dari utara ke selatan. Terdapat beberapa sungai besar (Sungai Kapuas, Sungai Sambas, Sungai Mempawah, Sungai Pemangkat, dan Sungai Duri) yang bermuara ke pesisir pantai Kalimantan Barat dan berinteraksi langsung dengan Laut Natuna dan Selat Karimata[1]. Kalimantan Barat merupakan salah satu propinsi yang memiliki dua waktu puncak musim hujan yaitu bulan April dan bulan Oktober [2]. Kondisi ini menyebabkan daerah pesisir Kalimantan Barat mendapat suplai air tawar dan material sedimen yang relatif lebih besar dibandingkan daerah pesisir propinsi lain. Massa air yang masuk dari sungai-sungai tersebut selanjutnya akan berinteraksi dengan massa air laut perairan laut
Kalimantan Barat yang selanjutnya bergerak sesuai dengan pola arus di wilayah tersebut. Suplai massa air dari sungai-sungai besar dari bagian selatan mempengaruhi kualitas air di perairan laut Kalimantan Barat [3].

Daerah limpasan massa air tawar dari sungai menghasilkan sistem sirkulasi kompleks dengan sifat yang sangat berbeda dengan air laut $[4,5,6]$. Massa air laut akan mengalir ke muara sampai pada jarak yang cukup jauh ketika pasang, sedangkan ketika surut massa air keluar lagi dari muara menuju ke laut [7]. Pertemuan massa air tawar dari sungai dengan massa air laut yang bersifat asin pada perairan pantai akan membentuk massa air bersalinitas rendah (MABR) dan membentuk sistem pesisir yang didominasi oleh wilayah yang dipengaruhi air tawar (region of freswater influence, ROFI); istilah yang diperkenalkan oleh Simpson et al. [8] untuk mendemarkasi wilayah khas ini di laut pesisir dan lautan. Aliran air tawar mengarah ke 
stratifikasi, sementara kekuatan lain (gelombang, angin dan pasut) menghasilkan pencampuran kolom air secara vertikal.

Penelitian sejenis juga dilakukan oleh Nurjaya (2000) tentang karakteristik MABR di Teluk Tokyo pada 4 musim yang berbeda, yaitu mengenai daerah limpasan massa air tawar dari sungai yang menghasilkan sistem sirkulasi kompleks dengan sifat yang sangat berbeda dengan air laut [9]. Penelitian tentang ROFI di daerah ekuator telah dilakukan sebelumnya oleh Sulardi (2016) yang mendeskripsikan kondisi hidro-oseanografi dan melihat variasi MABR bulanan di Perairan Teluk Balikpapan [10]. Penelitian tersebut dilakukan pada sistem perairan teluk yang relatif tertutup sedangkan perairan laut Kab. Bengkayang Kalimantan Barat merupakan perairan terbuka yang menghadap ke Laut Natuna dan Selat Karimata.

Dinamika ROFI yang terjadi di perairan laut Kabupaten Bengkayang (termasuk di sekitar Pulau Lemukutan) akan mempengaruhi parameter biofisik dan kesuburan perairan. Parameter biofisik utama yang akan terdampak oleh dinamika ROFI adalah salinitas, temperatur dan arus. Demikian pula dengan kandungan nitrat dan fosfat akan mengalami perubahan seiring dengan dinamika ROFI yang membawa material sedimen dari hulu sungai. Hutabarat dan Evans menyebutkan bahwa hampir semua organisme laut hanya dapat hidup pada daerah yang mempunyai perubahan salinitas yang kecil. Kontribusi air tawar yang masuk ke laut melalui sungai menyebabkan kisaran salinitas yang besar pada daerah pantai, sedangkan organisme memerlukan keadaan yang stabil[11].

Daerah penelitian ini dipilih karena di daerah ini terjadi fenomena kemunculan MABR yang pada musim kemarau setiap tahun dengan intensitas yang beragam. Kemunculan MABR ini terjadi hanya dalam rentang waktu 5 s.d 7 hari. Massa air bersalinitas rendah ini sangat mempengaruhi kehidupan biota laut yang ada di daerah penelitian terutama tanaman rumput laut yang dibudidayakan oleh masyarakat setempat. Berdasarkan hal tersebut, perlu dilakukan penelitian yang mengkaji sebaran salinitas perairan laut Kabupaten Bengkayang.

\section{Metodologi}

Pengambilan data lapangan dilakukan pada tanggal 9 dan 10 Mei 2018 yang bertepatan dengan kondisi musim kemarau yang bertepatan dengan kemunculan MABR di perairan Pulau Lemukutan. Pengambilan data dilakukan tanpa memperhitungkan kondisi pasang surut. Pengukuran dilakukan beberapa hari setelah adanya laporan dari masyarakat tentang kemunculan MABR di perairan Pulau Lemukutan Kabupaten Bengkayang. Fenomena MABR yang bisa menjangkau sampai daerah Pulau Lemukutan (jangkauan terjauh) justru terjadi pada musim kemarau. Masukan air tawar dari sungai dalam jumlah yang cukup besar

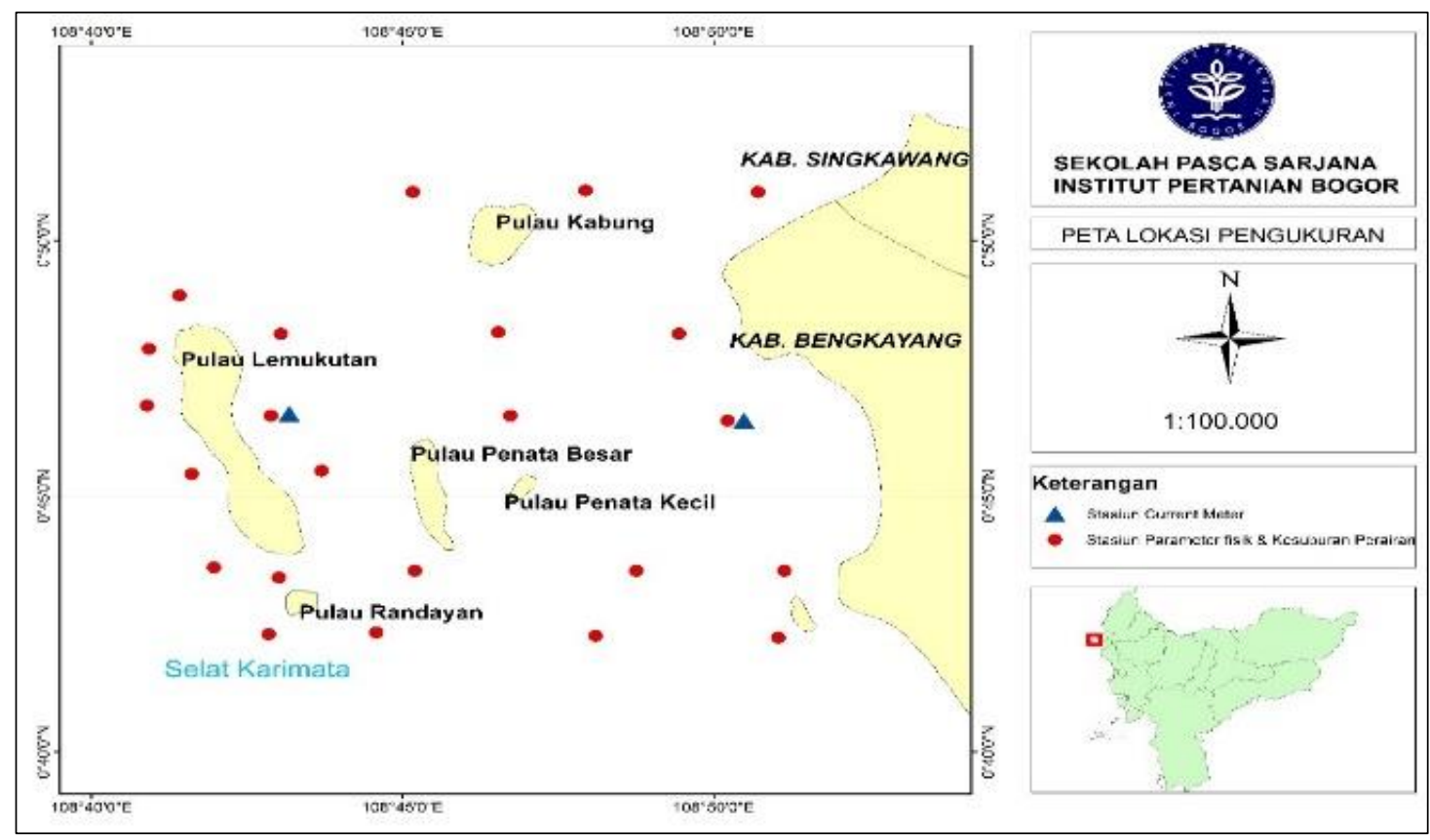

Gambar 1. Lokasi penelitian dan posisi stasiun pengukuran yang ditunjukkan oleh titik berwarna merah 
ke daerah penelitian juga terjadi pada musim kemarau. Hal ini terjadi karena Kalimantan Barat mengalamai dua kali puncak musim hujan [2].

Lokasi penelitian berada pada koordinat 107,68 s.d 108,93 BT dan 0,69 LS s.d 0,87 LU. Lokasi penelitian terdiri atas lima lintasan yang membentang dari timur ke barat dan setiap lintasan terdiri atas empat stasiun pengamatan serta penambahan tiga stasiun pengukuran di sisi timur, barat dan selatan Pulau Lemukutan, seperti ditunjukkan pada Gambar 1. Pengukuran salinitas dan temperatur berdasarkan kedalaman dilakukan dengan menggunakan conductivity temperature depth (CTD) minosx. Data kedalaman diambil dengan mengggunakan alat depth finder, dan data posisi stasiun pengukuran diperoleh dengan mengunakan global positioning sistem (GPS).

Analisis dan visualisasi data massa air (suhu, salinitas, dan densitas) dilakukan dengan menggunakan perangkat lunak Ocean Data View (ODV) versi 4.7.6. [12]. Perangkat lunak ini mempunyai kemampuan memvisualissikan data oseanografi terutama data hasil perekaman dari CTD. Visualisasi ODV berupa sebaran menegak (scatter), melintang (section) berdasarkan jarak dan koordinat (longitude dan latitude), permukaan dan stasiun. Analisis dan visualisasi data massa air dilakukan untuk mengetahui sebaran salinitas massa air di ROFI perairan laut Kabupaten Bengkayang pada musim kemarau.

\section{Hasil dan Pembahasan}

Gambar 2 menunjukkan sebaran salinitas permukaan perairan laut Kabupaten Bengkayang. Gambar 3 merupakan profil menegak salinitas dan diagram T-S di setiap stasiun pengukuran. Gambar
5 menunjukkan profil menegak sebaran salinitas dari empat lintasan arah utara - selatan (sejajar garis pantai) dan Gambar 6 menggambarkan profil menegak sebaran salinitas lintasan arah timur barat (tegak lurus garis pantai).

\section{A. Sebaran Permukaan Salinitas}

Gambar 2 menunjukkan sebaran salinitas permukaan di perairan laut Kabupaten Bengkayang hingga sisi barat Pulau Lemukutan. Sebaran nilai salinitas permukaan di daerah penelitian yaitu 28,96 psu s.d 31,5 psu (selisih 2 psu). Secara umum, sebaran salinitas permukaan di daerah penelitian terdiri atas tiga bagian yaitu bagian utara, bagian tengah dan bagian selatan daerah penelitian. Bagian utara daerah penelitian merupakan daerah bersalinitas tinggi (30,75 s.d 31,50 psu) yang membentang dari arah timur ke barat di bagian utara daerah penelitian, mulai dari sisi sebelah timur Pulau Kabung (sekitar Stasiun 16) hingga ke perairan bagian utara Pulau Lemukutan. Walaupun ditemukan massa air bersalinitas rendah (29,5 psu) di daerah sekitar pantai bagian utara daerah penelitian (Stasiun 17b). Daerah bersalinitas rendah (29,5 s.d 30,25 psu) dijumpai pada sisi barat dan timur Pulau Lemukutan, sebelah utara Pulau Penata Besar dan Pulau Penata Kecil serta bagian timur Pulau Penata Kecil. Bagian selatan daerah penelitian merupakan daerah dengan salinitas 30,5 psu s.d 31,0 psu. Daerah dengan nilai salinitas tersebut membentang di bagian selatan daerah penelitian yaitu dari sisi sebelah barat Pulau Randayan hingga perairan sekitar Pulau Semesak.

Sebaran salinitas permukaan di daerah penelitian yang terbagi menjadi tiga bagian (bagian utara, bagian tengah dan bagian selatan) tersebut
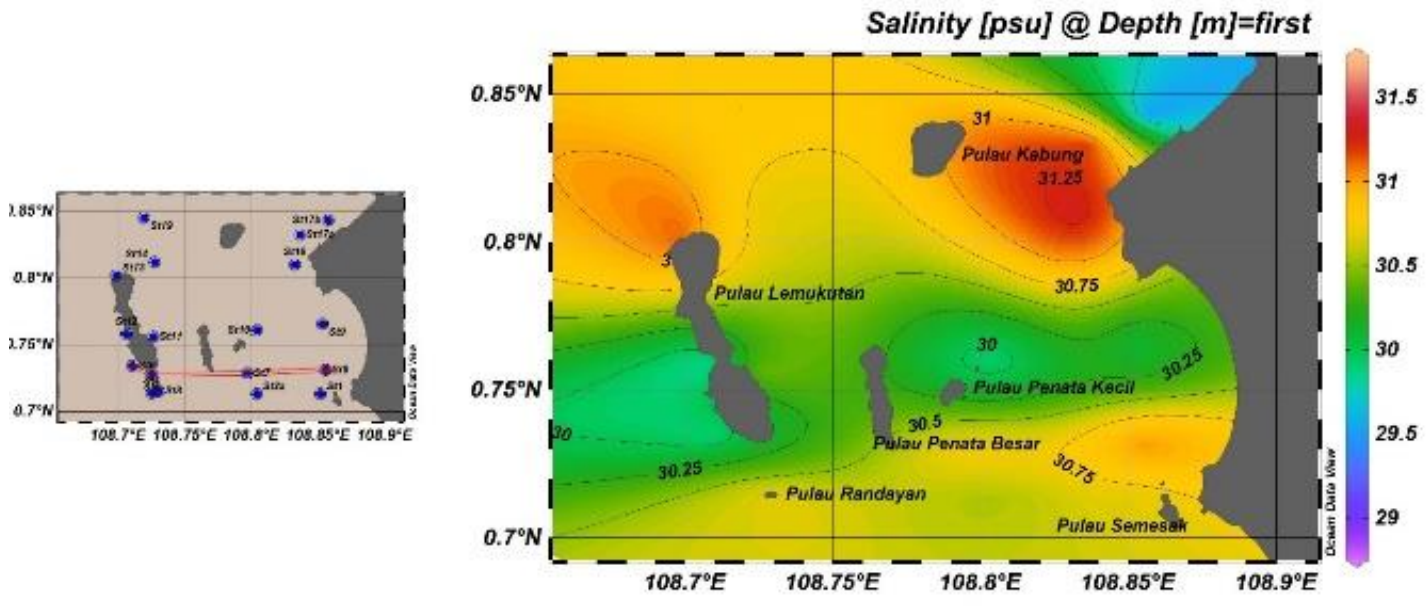

Gambar 2. Sebaran salinitas permukaan perairan laut Kabupaten Bengkayang. Sebaran salinitas massa air di daerah penelitian terbagi menjadi tiga bagian yaitu: bagian utara, bagian tengah dan bagian selatan yang masing-masing membentang dari timur ke barat. 
mengindikasikan bahwa massa air tawar dari beberapa sungai yang kemudian bercampur dengan massa air tawar membentuk massa air baru dengan salinitas dan temperature tertentu. Massa air tawar yang terjebak di bagian tengah tersebut diduga berasal dari massa air dari sungai yang terletak di bagian selatan pesisir Kalimantan yaitu Sungai Kapuas dan Sungai Mempawah. Massa air baru yang terjebak tersebut kemudian terdorong dan bergerak ke arah utara sesuai dengan arah arus yang terjadi di pesisir Kalimantan Barat pada musim kemarau. Pada musim timur (kemarau), arus di perairan pantai sekitar Sungai Duri bergerak ke arah utara hingga barat daya [13]. Pergerakan massa air baru yang bergerak tersebut selanjutnya akan tertahan oleh massa air laut bersalinitas lebih tinggi di bagian utara daerah penelitian.

\section{B. Sebaran Menegak Salinitas}

Kurva T-S biasanya digunakan untuk menggambarkan keunikan sebuah perairan. Kurva T-S suatu perairan berbeda dengan diagram T-S perairan yang lain. Masing-masing perairan memiliki kurva T-S yang unik sehingga kurva T-S suatu perairan merupakan "sidik jari" perairan tesebut. Kurva T-S dapat digunakan untuk mengidentifikasi massa air dan proses pencampuran. Selain itu, kurva T-S juga digunakan untuk melihat kestabilan kolom air berdasarkan sifat perpotongannya dengan kurva densitas (kurva sigma-t, $\sigma_{t}$ ). Suatu kolom air dikatakan stabil jika kurva T-S memotong kurva $\sigma_{\mathrm{t}}$ ke arah bawah (ke arah pertambahan $\sigma \mathrm{t}$ ). Bila kurva T-S memotong kurva $\sigma \mathrm{t}$ ke arah atas (kearah pengurangan $\sigma_{t}$ ) maka kolom air dikatakan tidak stabil. Bila kurva T$S$ sejajar dengan kurva $\sigma_{t}$ maka kolom air netral.

Densitas air laut adalah fungsi dari salinitas, suhu dan tekanan (kedalaman). Densitas akan bertambah besar bila salinitas bertambah, suhu berkurang dan tekanan (kedalaman) bertambah. Di lapisan permukaan, perubahan densitas sangat ditentukan oleh salinitas dan suhu air laut. Pengaruh suhu lebih dominan daripada pengaruh salinitas.

Profil menegak sebaran salinitas dan kurva T-S beberapa stasiun yang memiliki MABR dengan nilai salinitas kurang dari 30,0 psu dapat dilihat pada Gambar 3. Dari gambar tersebut, dapat dilihat lima stasiun pengukuran yang memiliki profil salinitas menegak kurang dari 30 psu hingga kedalaman tertentu. Stasiun yang memiliki karakteristik yang unik yaitu stasiun 17b, Stasiun 5, Stasiun 12, Stasiun 10, dan Stasiun 9.

Salinitas yang terdapat di lima stasiun tersebut bersesuaian dengan sebaran horizontal salinitas. Massa air bersalinitas kurang dari 30,5 psu
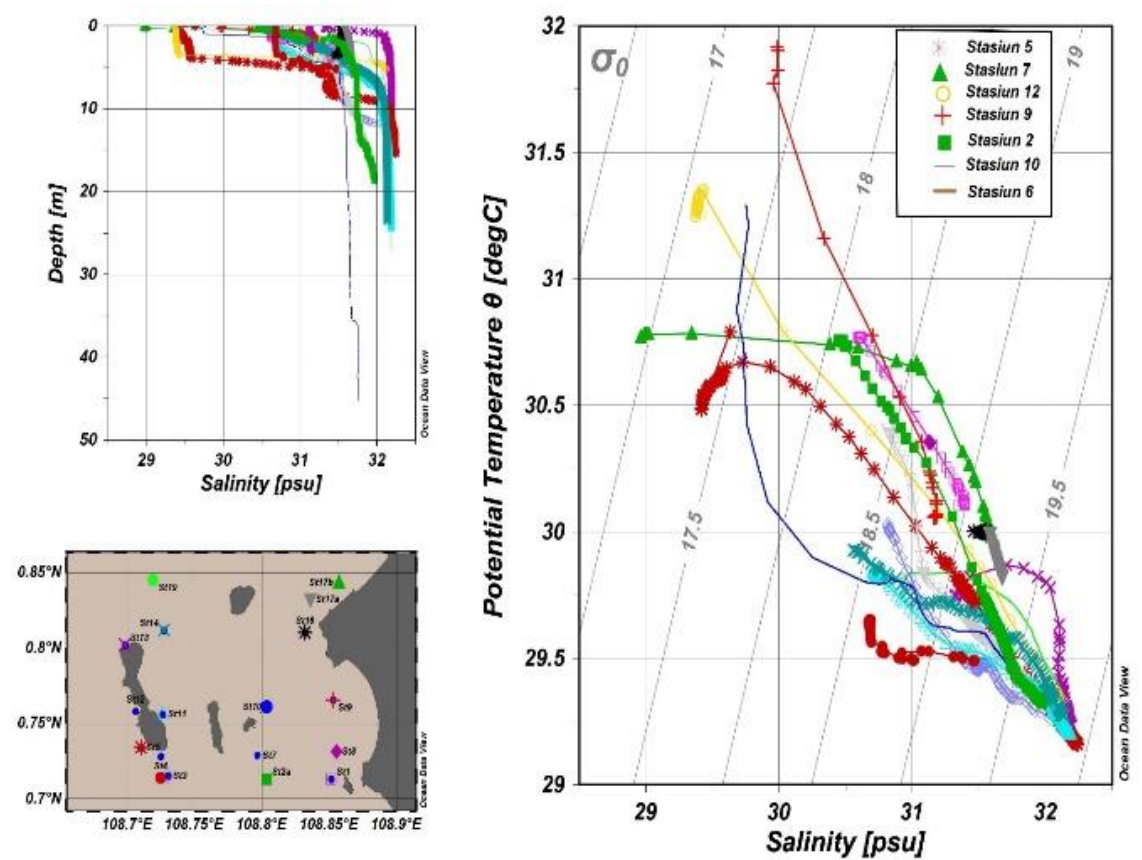

Gambar 3. Profil menegak salinitas dan diagram T-S beberapa stasiun yang memiliki massa air bersalinitas rendah (MABR) dengan nilai salinitas kurang dari 30,0 psu diberi simbol legenda tertentu pada kanan atas gambar. 
(salinitas rendah) di Stasiun 9 dan Stasiun 17b disebabkan oleh jarak yang dekat dari daratan Kalimantan yang merupakan sumber massa air tawar. Terdapat dua sungai kecil yang bermuara ke daerah pantai dari dua stasiun tersebut. Massa air bersalinitas kurang dari 30,5 psu di Stasiun 5, Stasiun 10 dan Stasiun 12 merupakan MABR yang masih bertahan di perairan Pulau Lemukutan dan sekitarnya. Kehadiran MABR tersebut dilaporkan oleh masyarakat mencapai Pulau Lemukutan beberapa hari sebelum dilakukan pengukuran. MABR tersebut, menurut masyarakat pulau, tiap tahun dapat dijumpai di Pulau Lemukutan pada musim kemarau (bulan Mei atau Juni). Kehadiran MABR di Pulau Lemukutan menurut masyarakat Pulau Lemukutan biasanya berlangsung 5 hingga 7 hari. Angin pada hari pengukuran bertiup ke arah barat laut (angin tenggara). Angin tenggara ini membentuk pola arus tenggara (arus yang bergerak dari arah tenggara) yang terjadi pada bulan Mei hingga Oktober [3]. Hal ini bersesuaian dengan penelitian yang dilakukan Suandi pada tahun 2018 yang menyebutkan bahwa pada musim timur, arus di perairan pantai sekitar Sungai Duri bergerak ke arah utara hingga barat daya [13]. Angin yang terjadi pada tanggal 10 Mei 2018, pada saat pengukuran dilakukan, ditunjukkan pada Gambar 4. Data angin tersebut diperoleh dari website: www.esrl.noaa.gov ${ }_{2}$ kemudian diolah dengan menggunakan software GrADS.

Kedalaman lapisan mix layer (berdasarkan nilai salinitas) dan kedalaman maksimum massa air bersalinitas kurang dari 30,5 psu serta jarak stasiun pengukuran dari garis pantai terdekat dari daratan Pulau Kalimantan ditunjukkan pada Tabel 1. Massa air di seluruh stasiun pengamatan menunjukkan kondisi stabil dalam arah vertikal, massa air terstratifikasi sesuai dengan nilai densitasnya.

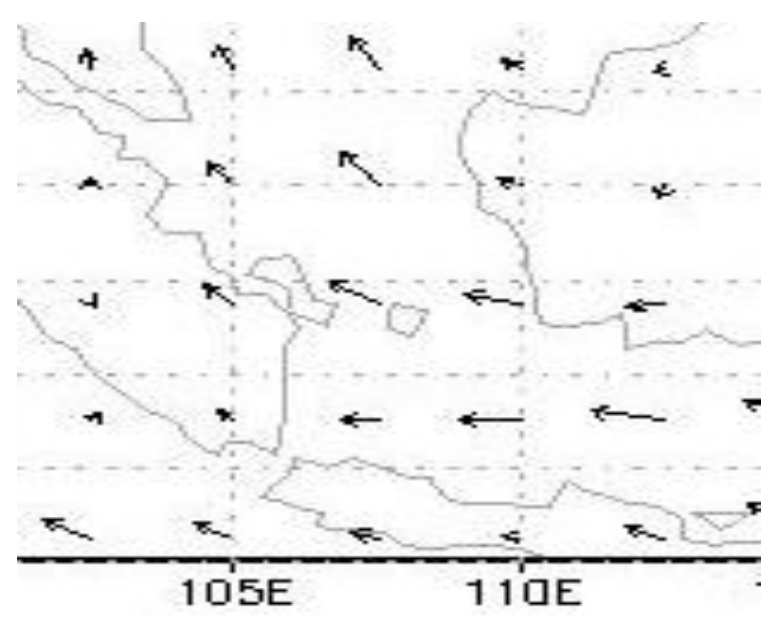

Gambar 4. Vektor angin di perairan Selat Karimata dan pesisir pantai Kalimantan Barat pada tanggal 10 Mei 2018 yang menunjukkan arah angin di daerah penelitian bergerak dari arah tenggara. Data angin tersebut diperoleh dari website: www.esrl.noaa.gov kemudian diolah dengan menggunakan software GrADS.

Massa air dengan densitas yang kecil berada di atas massa air dengan densitas yang lebih besar. Tidak ditemukan kurva T-S yang memotong kurva densitas $\sigma_{t}$ ke arah atas (ke arah pengurangan densitas $\sigma_{t}$ ).

Massa air bersalinitas kurang dari 30,5 psu dengan kedalaman yang bervariasi dapat dijumpai pada beberapa lintasan yang sejajar garis pantai maupun di lintasan yang tegak lurus dengan garis pantai. Pada lintasan yang sejajar garis pantai (oritentasi utara - selatan), massa air dengan salinitas yang kurang dari 30,5 psu terdapat pada lintasan pertama dan lintasan keempat dari garis pantai.

Lintasan pertama adalah lintasan yang terdekat dengan garis pantai pesisir pantai Kabupaten Bengkayang sedangkan lintasan keempat adalah lintasan yang terletak di sebelah barat Pulau Lemukutan. Sebaran secara menegak

Tabel 1. Beberapa parameter fisik massa air di stasiun pengukuran yang memiliki nilai salinitas yang kuran dari 30,5 psu, kedalaman mix layer didasarkan pada nilai salinitas dan pycnocline.

\begin{tabular}{|l|c|c|c|c|c|c|}
\hline Lokasi & $\begin{array}{c}\text { Kedalaman } \\
\text { dasar (m) }\end{array}$ & $\begin{array}{c}\text { Kedalaman } \\
\text { Mix Layer } \\
\text { (m) }\end{array}$ & $\begin{array}{c}\text { Salinitas } \\
\text { di lapisan } \\
\text { mix layer } \\
\text { (psu) }\end{array}$ & $\begin{array}{c}\text { Salinitas } \\
\text { permukaan } \\
\mathbf{( p s u )}\end{array}$ & $\begin{array}{c}\text { Kedalaman } \\
\text { maksimum } \\
\text { massa air } \\
\text { bersalinitas } \\
\text { kurang dari 30,5 } \\
\text { psu (m) }\end{array}$ & $\begin{array}{c}\text { Jarak } \\
\text { dari garis } \\
\text { pantai } \\
\text { (km) }\end{array}$ \\
\hline Stasiun 5 & 16 & 3,8 & 29,58 & 29,43 & 4,5 & 15,5 \\
\hline Stasiun 9 & 3 & 0,2 & 29,99 & 29,99 & 0,4 & 3,2 \\
\hline Stasiun 10 & 45 & 1,0 & 29,76 & 29,68 & 1,2 & 8,9 \\
\hline Stasiun 12 & 5 & 3,5 & 29,40 & 29,37 & 3,6 & 19,8 \\
\hline Stasiun 17 & 4 & 0,3 & 28,99 & 28,96 & 0,5 & 2,2 \\
\hline
\end{tabular}



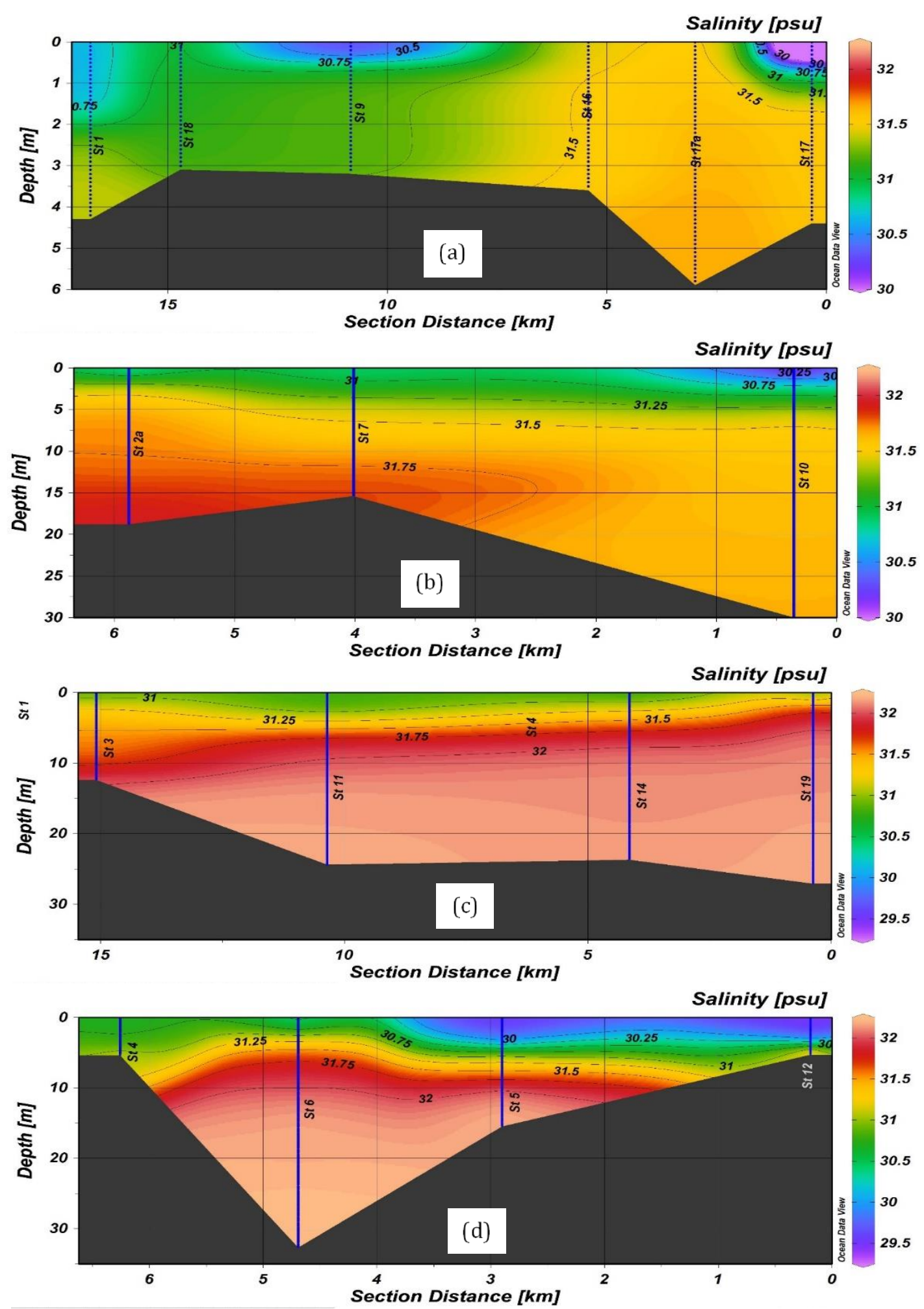

Gambar 5.Profil menegak sebaran salinitas dari empat lintasan arah Utara - Selatan (sejajar garis pantai). (a) Lintasan pertama dari garis pantai (b) Lintasan kedua dari garis pantai (c) Lintasan ketiga dari garis pantai (d) Lintasan keempat dari garis pantai.

massa air bersalinitas kurang dari 30,5 psu pada lintasan yang sejajar garis pantai dapat dilihat pada Gambar 5. Lintasan ditunjukkan oleh garis merah ganda yang menghubungkan beberapa stasiun pengukuran yang terdapat pada sketsa lokasi penelitian di tiap gambar penampang menengak.
Pada lintasan pertama, massa air bersalinitas kurang dari 30,5 psu terdapat pada daerah sekitar stasiun $17 \mathrm{~b}$ dan pada daerah sekitar stasiun 9 dengan masing-masing berada pada kedalaman 30 s.d $70 \mathrm{~cm}$ dari permukaan. Pada daerah sekitar Stasiun 17b, massa air bersalinitas kurang dari 30 

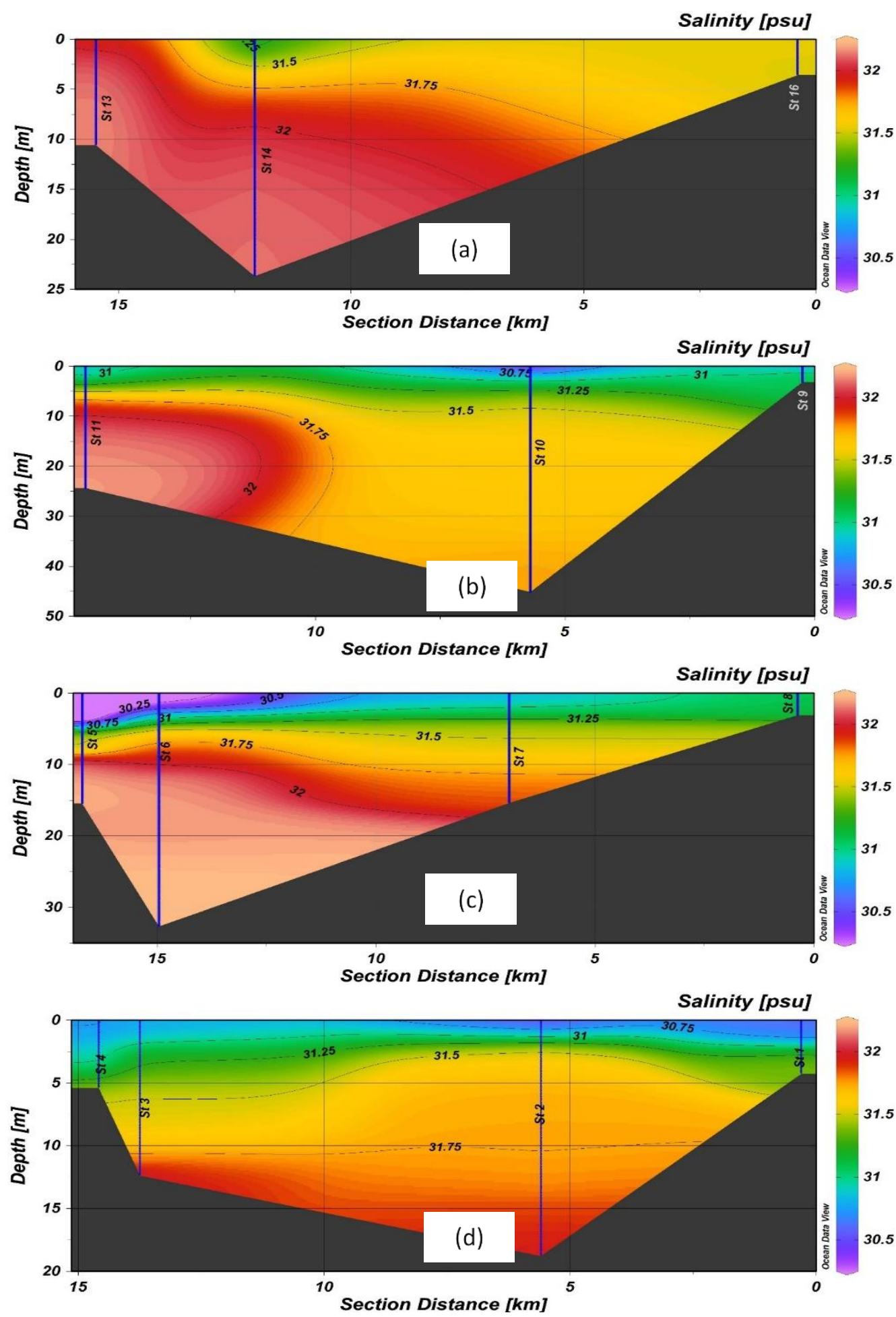

Gambar 6. Profil menegak sebaran salinitas dari empat lintasan arah Timur - Barat (tegak lurus garis pantai). (a) Lintasan pertama dari utara (b) Lintasan kedua dari utara (c) Lintasan ketiga dari utara (d) Lintasan keempat dari utara.

psu membentang dari utara ke selatan hanya sekitar $1 \mathrm{~km}$, sedangkan pada daerah sekitar Stasiun 9 membentang dari utara ke selatan sekitar $5 \mathrm{~km}$.

Massa air bersalinitas kurang dari 30,5 psu yang sampai pada kedalaman 5 meter dan membentang dari utara ke selatan dengan jarak sekitar
$4 \mathrm{~km}$ terdapat pada lintasan di sebelah barat Pulau Lemukutan. Massa air tersebut membentang dari Utara ke selatan pada daerah sekitar Stasiun 12 di bagian Utara hingga ke daerah bagian selatan Stasiun 5. Posisi stasiun dan kedalaman massa air yang kurang dari 30,5 psu dapat dilihat pada Tabel 1. 
Massa air bersalinitas kurang dari 30,5 psu yang terjebak di lintasan keempat dari garis pantai (sisi barat Pulau Lemukutan) dalam jumlah yang banyak hingga mencapai kedalaman 4,5 meter mengindikasikan bahwa terjadi keseragaman arah arus dalam rentang yang jauh dari pantai yang bergerak ke arah barat laut yang mendorong MABR yang berasal dari sungai pesisir Kalbar bagian selatan. Sungai yang terletak di bagian selatan pesisir Kalbar yaitu Sungai Kapuas dan Sungai Mempawah.

Sebaran secara menegak massa air bersalinitas kurang dari 30,5 psu pada lintasan yang tegak lurus garis pantai dapat dilihat pada Gambar 6. Lintasan ditunjukkan oleh garis merah ganda yang menghubungkan beberapa stasiun pengukuran yang terdapat pada sketsa lokasi penelitian di tiap gambar penampang menengak. Dari Gambar 6 tersebut, terlihat bahwa dari empat lintasan penampang melintang yang tegak lurus garis pantai, massa air bersalinitas kurang dari 30,5 psu terdapat pada lintasan kedua (Gambar 6b) dan lintasan ketiga (Gambar 6c). Pada lintasan kedua dari utara, massa air bersalinitas kurang dari 30,5 psu terdapat pada Stasiun 10 dengan jarak kurang dari $1 \mathrm{~km}$ dan hanya berada pada kedalaman sekitar 1 meter dari permukaan. Pada lintasan ketiga dari utara, massa air bersalinitas kurang dari 30,5 dijumpai pada bagian barat lintasan yaitu di Stasiun 6 dan Stasiun 5 (di bagian selatan dan barat daya Pulau Lemukutan). Pada lintasan ketiga dari utara ini, massa air di kedalaman yang lebih besar dari 10 meter salinitasnya semakin bertambah seiring bertambahnya kedalaman (dari 31,75 psu hingga 32,5 psu). Dari Gambar 6, juga terlihat bahwa massa air dengan salinitas 30,75 s.d 31,75 psu dapat dijumpai dari garis pantai hingga mencapai bagian barat Pulau Lemukutan dengan kedalaman sampai 10 meter dari permukaan (lihat Gambar 6c dan Gambar 6d). Massa air bersalinitas 31,75 psu bahkan bisa dijumpai hingga kedalaman 40 meter di daerah sekitar Stasiun 10 dengan jarak sekitar $10 \mathrm{~km}$ dari garis pantai pesisir pantai Kabupaten Bengkayang (lihat Gambar 6b).

\section{Kesimpulan}

Salinitas massa air di perairan laut Kabupaten Bengkayang pada musim kemarau adalah pada rentang 28,96 s.d 32,5 psu. Secara umum sebaran salinitas permukaan di daerah penelitian terdiri atas tiga bagian yaitu bagian utara, bagian tengah dan bagian selatan daerah penelitian, dengan tiap bagian membentang dari timur ke barat atau tegak lurus garis pantai. Massa air permukaan yang memiliki salinitas tertinggi berada di bagian utara $(30,75$ s.d $31,50 \mathrm{psu})$ kemudian menyusul bagian selatan $(30,5$ psu s.d 31,0 psu) dan bagian tengah (29,5 s.d 30,25 psu). MABR yang terjebak di bagian tengah tersebut diduga berasal dari massa air dari sungai yang terletak di bagian selatan pesisir Kalimantan yaitu Sungai Kapuas dan Sungai Mempawah.

Massa air di seluruh kolom air stasiun pengukuran menunjukkan kondisi stabil dalam arah vertikal. Massa air dengan densitas yang kecil berada di atas massa air dengan densitas yang lebih besar. Massa air yang bersalinitas kurang dari 30,5 psu ditemukan hingga kedalaman 4,5 meter di bagian barat daya, bagian selatan dan bagian tenggara Pulau Lemukutan. Hal ini mengindikasikan bahwa terjadi keseragaman arah arus dalam rentang yang jauh dari pantai yang bergerak ke arah barat laut yang mendorong MABR yang berasal dari perairan pesisir Kalimantan Barat bagian selatan yang terbawa arus ke arah Utara.

Massa air dengan salinitas 30,75 s.d 31,75 psu dapat dijumpai dari garis pantai hingga mencapai bagian barat Pulau Lemukutan dengan kedalaman sampai 10 meter dari permukaan. Hal ini menunjukkan bahwa massa air yang berada di daerah sekitar garis pantai perairan pesisir Kabupaten Bengkayang dapat mencapai perairan sekitar Pulau Lemukutan.

\section{Ucapan Terima Kasih}

Terima kasih kami sampaikan kepada: Kepala Laboratorium Oseanografi, Biologi dan Geologi Departemen Ilmu dan Teknologi Kelautan Fakultas Perikanan dan Ilmu Kelautan Institut Pertanian Bogor atas peminjaman alat pengukuran dan suplai tenaga lapangan, Kepala Laboratorium Fisika Jurusan Fisika Fakultas Matematika dan Ilmu Pengetahuan Alam Universitas Tanjungpura atas peminjaman alat penelitian, Saudara Apriansyah Hakim atas kesediaanya memberikan peminjaman peralatan penelitian milik pribadi yang kami gunakan dalam pengambilan data, dan adik-adik asisten Laboratorium Kelautan Jurusan Kelautan Fakultas Matematika dan Ilmu Pengetahuan Alam Universitas Tanjungpura atas bantuan tenaga dan dedikasi yang luar biasa saat persiapan dan pengambilan data lapangan. 


\section{Daftar Pustaka}

[1] Balai Pusat Statistik Kalimantan Barat Provinsi Kalimantan Barat Dalam Angka 2019. (2019).

[2] Aldrian, E. and Dwi Susanto, R. , Identification of three dominant rainfall regions within Indonesia and their relationship to sea surface temperature, International Journal of Climatology, 23(12), pp.1435-1452, 2003.

[3] Kushadiwijayanto, A. A., Apriansyah, H., and Idiawati, N. In Pemodelan Arus Musiman Di Perairan Lemukutan Kalimantan, Fakultas Keguruan dan Ilmu Pendidikan (FKIP) bekerjasama dengan Fakultas Sains dan Teknologi (FST) Universitas Jambi: Jambi(ID), 2017.

[4] Nakada S, Ishikawa Y, Awaji T, In T, Shima S, Nakayama T, Isada T, S. S. , Modelling run off into a Region of Freswater Influence for improved ocean predicted: Application to Funka Bay, J-STAGE, 6pp.47-52, 2012.

[5] Tas, S. . Region of Freswater Influence: The Influence of Depth on ROFI. Faculty of Civil Engineering, Delft University of Technology, Delft(NL). 2014, 2014.

[6] Souza, A. J. and Simpson, J. H. , The modification of tidal ellipses by stratification in the Rhine ROFI, Continental Shelf Research, 16(8), pp.997-1007, 1996.
[7] Triatmodjo, B., Teknik Pantai,Beta Offset, 1999.

[8] Simpson, J.H., Bos, W.G., Schirmer, F., Souza, A.J., Rippeth, T.P., Jones, S.E., \& Hydes, D., Periodic stratification in the Rhine ROFI in the North Sea, Oceanologica Acta, 16(1), pp.23-32, 1993.

[9] Nurjaya, I. W., Behavior of Low Salinity Water Near The Mouth of Tokyo Bay. Tokyo University of Fisheries, Tokyo (JP). 2000, 2000.

[10] Sulardi, A., Karakteristik Massa Air Bersalinitas Rendah Di Perairan Teluk Balikpapan Anom Sulardi. Fakultas Perikanan dan Ilmu Kelautan, Institut Pertanian Bogor (ID). 2016, 2016.

[11] Hutabarat and Evans, Pengantar Oseonografi, Universitas Indonesia, 2001.

[12] Schlitzer, R. Ocean Data View. (2014).

[13] Suandi, Jumarang, M. I., and Apriansyah, Analisis Pola Sirkulasi Arus di Perairan Pantai Sungai Duri Kabupaten Bengkayang Kalimantan Barat, Positron, 6(2), pp.60, 2016. 